\title{
Rancang Bangun Sistem Penyewaan Lapangan Futsal Menggunakan CodeIgniter Pada 3R Futsal
}

\author{
Eva Rahmawati ${ }^{1}{ }^{*}$, Nanang Nuryadi ${ }^{2)}$, Haikal Aserih ${ }^{3)}$ \\ 1)3) Program Studi Teknik informatika, STMIK Nusa Mandiri \\ ${ }^{2)}$ Program Studi Teknik Komputer, Universitas Bina Sarana Informatika \\ ${ }^{*}$ Correspondence Author: eva.ehw@bsi.ac.id, Jakarta, Indonesia \\ DOI: https://doi.org/10.37012/jtik.v7i1.503
}

\begin{abstract}
Abstrak
Sistem penyewaan lapangan futsal pada 3R Futsal masih bersifat manual. Pemesan lapangan harus datang ke 3R Futsal. Selain itu bukti pembayaran masih menggunakan banyak kertas atau buku untuk membuat laporan pembayaran. Pengelola mengalami kesulitan jika ingin melakukan rekap data karena ada banyak kertas yang dikumpulkan dan tidak terorganisir penyimpaannya. Data pemesanan dan penggunaan lapangan futsal mudah hilang. Supaya tidak terjadinya bentrokan jam/jadwal satu customer dengan customer lain, maka digunakan teknologi komputer khususnya Sistem Informasi berbasis website untuk melakukan pemrosesan. Penggunaan teknologi merupakan cara untuk mengelola proses dengan baik. Dengan adanya implementasi Sistem Penyewaan Lapangan Futsal ini membantu memudahkan 3R Futsal dalam pemrosesan penyewaan lapangan. Sistem Informasi penyewaan lapangan futsal ini dapat memudahkan karyawan dalam pembuatan laporan penyewaan lapangan futsal setiap bulan atau setiap tahun. Sistem informasi penyewaan lapangan futsal berbasis web yang telah dirancang ini dapat meminimalisir kesalahan manusia atau human error.
\end{abstract}

Kata kunci: Sistem informasi, penyewaaan, CodeIgniter

\begin{abstract}
The futsal court rental system at 3R Futsal is still manual. The field orderer must come to $3 R$ Futsal. In addition, proof of payment still uses a lot of paper or books to make payment reports. Managers have difficulty if they want to recap the data because there are a lot of papers that are collected and not organized. Ordering data and use of the futsal court are easy to lose. In order not to clash of hours / schedules for one customer with another customer, computer technology, especially website-based Information Systems, is used to carry out the processing. The use of technology is a way to manage processes well. With the implementation of the Futsal Field Rental System, it helps facilitate the 3R Futsal in processing field rentals. This futsal field rental information system can make it easier for employees to make reports on the rental of futsal fields every month or every year. This web-based futsal court rental information system that has been designed can minimize human error.
\end{abstract}

Keywords: Information systems, leasing, CodeIgniter

\section{PENDAHULUAN}

Dalam era globalisasi yang sangat pesat sekarang ini perkembangan teknologi sangat dibutuhkan oleh banyak perusahaan atau instansi. Teknologi dapat memberikan informasi berbasis website, secara cepat dan akurat. Dengan kemajuan teknologi informasi, pengaksesan terhadap data atau informasi yang tersedia dapat berlangsung dengan cepat, efisien serta akurat. Contoh dari hasil kemajuan teknologi informasi adalah berkembangnya jaringan Internet yang memungkinkan seluruh umat manusia di seluruh 
dunia menggunakan data-data yang tersedia/terhubung dalam jaringan tersebut secara bersama-sama. Hal itu menjadikan komputer memegang peranan penting untuk percepatan dalam bidang sistem informasi, seperti mempercepat pengolahan data ketika mengambil keputusan. Dari pengamatan yang dilakukan pengelolaan bisnis penyewaan lapangan futsal masih dilakukan secara konvensional serta proses pembayaran yang masih sangat rentan terjadi kecurangan. Dalam mengatasi masalah tersebut, maka diperlukan implementasi aplikasi sistem informasi penyewaan lapangan futsal yang dapat melakukan proses penyewaan yang lebih cepat dan tepat. Dalam hal ini menggunakan sistem informasi berbasis web dengan menggunakan CodeIgniter.

\section{METODE}

Menurut Rosa dan Shalahuddin model Waterfall adalah model SDLC (System Development Live Cycle) yang paling sederhana. Model ini hanya cocok untuk pengembangan perangkat lunak dengan spesifikasi yang tidak berubah-ubah. Dalam penelitian ini digunakan model pengembangan sistem Waterfall. Model waterfall sering juga disebut model sekuensial linier (sequential linear) atau alur hidup klasik (classic life cycle). Model air terjun (waterfall) menyediakan pendekatan alur hidup perangkat lunak secara sekuensial atau terurut dimulai dari analisis, desain, pengkodean, pengujian, dan tahap pendukung (support).

Menurut Susanto sistem informasi adalah kumpulan dari subsistem apapun baik phisik ataupun non phisik yang saling berhubungan satu sama lain dan bekerja sama secara harmonis untuk mencapai satu tujuan yaitu mengolah data menjadi informasi yang berarti dan berguna.

Pemesanan (booking) dalam arti umum adalah perjanjian pemesanan tempat antara 2 (dua) pihak atau lebih, perjanjian pemesanan tempat tersebut dapat berupa perjanjian atas pemesanan suatu ruangan, kamar, tempat duduk dan lainnya, pada waktu tertentu dan disertai dengan produk jasanya. Produk jasa yang dimaksud adalah jasa yang ditawarkan pada perjanjian pemesanan tempat tersebut.

Website atau situs juga dapat diartikan sebagai kumpulan halaman yang menampilkan informasi data teks, data gambar diam atau gerak, data animasi, suara, video dan atau gabungan dari semuanya, baik yang bersifat statis maupun dinamis yang membentuk satu rangkaian bangunan yang saling terkait dimana masing-masing dihubungkan dengan jaringan-jaringan halaman (hyperlink). 
Entity Relationship Diagram (ERD) berisi komponen-komponen entitas dan himpunan relasi yang masing-masing dilengkapi dengan atribut-atribut yang mempresentasikan seluruh fakta yang ditinjau sehingga dapat diketahui hubungan antara entity-entity yang ada dengan atribut-atributnya. Selain itu juga bisa menggambarkan hubungan yang ada dalam pengolahan data, seperti hubungan many to many, one to many, one to one.

Logical Record Structure (LRS) digambarkan kotak persegi panjang dan dengan nama yang unik. File record pada LRS ditempatkan dalam kotak. LRS terdiri dari link di antara tipe record lainnya. Banyaknya link dari LRS yang diberi nama oleh filed-filed yang kelihatan pada kedua link tipe record.

Relasi antar tabel adalah hasil dari model entity relationship diagram. Relasi ini akan memperlihatkan rancangan fisik basis data dan juga akan menghasilkan tabel-tabel yang nantinya dapat digunakan dalam proses implementasi sistem.

Unified Modelling Language (UML) adalah bahasa pemodelan untuk sistem atau perangkat lunak yang berparadigma berorientasi objek. Konsep dasar UML terdiri dari structural classification, dynamic behavior, dan model management. UML mendefinisikan diagram-diagram sebagai Use case diagram, Class diagram, State chart diagram, Activity diagram, Sequence diagram, Collaboration diagram, Component diagram, dan Deployment diagram.

Menurut Sularno MySQL adalah suatu sistem manajemen basis data relasional. RDBMS (Relational Data base Management System) mampu bekerja dengan cepat, kokoh, dan mudah digunakan. Contoh RDBMS lain adalah Oracle, Sybase. Basis data memungkinkan untuk menyimpan, menelusuri, menurutkan dan mengambil data secara efesien. Server MySQL yang akan membantu melakukan fungsionalitas tersebut. Dalam rancangan sistem penyewaan lapangan futsal berbasis web pada lapangan $3 \mathrm{R}$ futsal ini, digunakan bahasa pemrograman PHP, CSS, HTML, Bootstrap, Javascript, dan menggunakan database SQL Sever.

Menurut Betha, Sidik CodeIgniter adalah Sebuah framework PHP yang bersifat open source dan menggunakan metode MVC (Model, View, Controller) untuk memudahkan developer atau programmer dalam membangun sebuah aplikasi berbasis web tanpa harus membuatnya dari awal. Dalam situs resmi codeigniter, menyebutkan bahwa codeigniter merupakan framework PHP yang kuat dan sedikit bug. Codeigniter ini dibangun untuk para pengembang dengan bahasa pemrogram PHP yang merupakan alat untuk membuat web dengan fitur lengkap. 
XAMPP adalah perangkat lunak bebas, yang mendukung banyak sistem operasi, merupakan kompilasi dari beberapa program. Fungsinya adalah sebagai server yang berdiri sendiri (localhost), yang terdiri atas program Apache HTTP Server, MySQL database, dan penerjemah bahasa yang ditulis dengan bahasa pemrograman PHP dan Perl. Nama XAMPP merupakan singkatan dari X (empat sistem operasi apapun), Apache, MySQL, PHP dan Perl. Program ini tersedia dalam GNU General Public License dan bebas, merupakan web server yang mudah digunakan yang dapat melayani tampilan halaman web yang dinamis. Untuk mendapatkanya dapat mendownload langsung dari web resminya.

\section{HASIL DAN PEMBAHASAN}

Analisa kebutuhan software untuk website dengan beberapa prosedur diantaranya:

Halaman Front-Page Admin:
a. Admin dapat melakukan login.
b. Admin dapat mengelola data transaksi.
c. Admin dapat mengelola data pengguna.
d. Admin dapat mengelola data lapangan.
e. Admin dapat melihat laporan transaksi

Halaman User:
a. User dapat mendaftar.
b. User dapat melakukan login.
c. User dapat melihat data lapangan.
d. User dapat memboking lapangan yang dipilih.
e. User dapat mengelola profil pengguna
f. User dapat mengelola data transaksi.
g. User dapat mengungah bukti bayar transaksi.
h. User dapat mencetak invoice. 


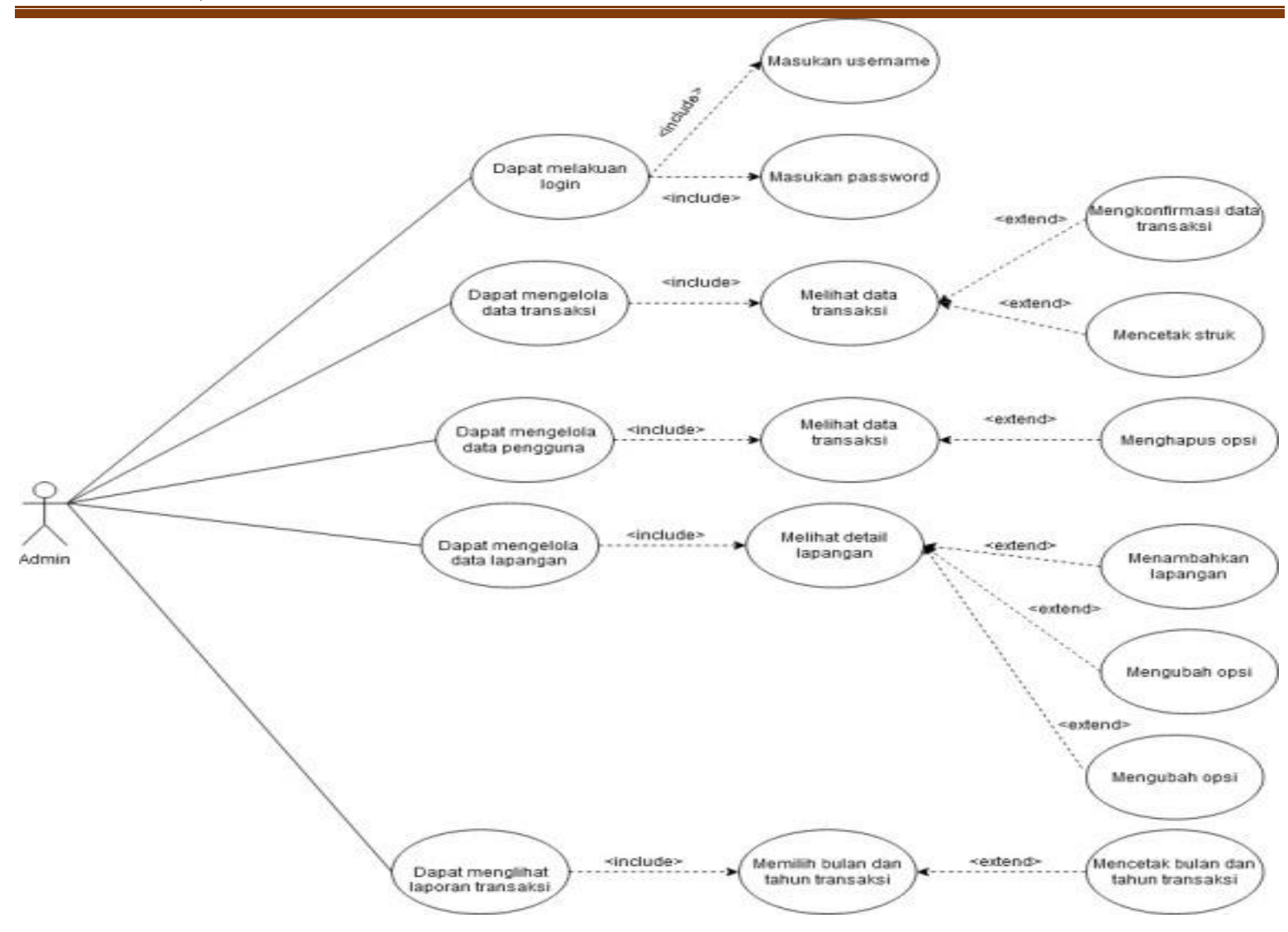

Gambar1. Use Case Diagram Admin

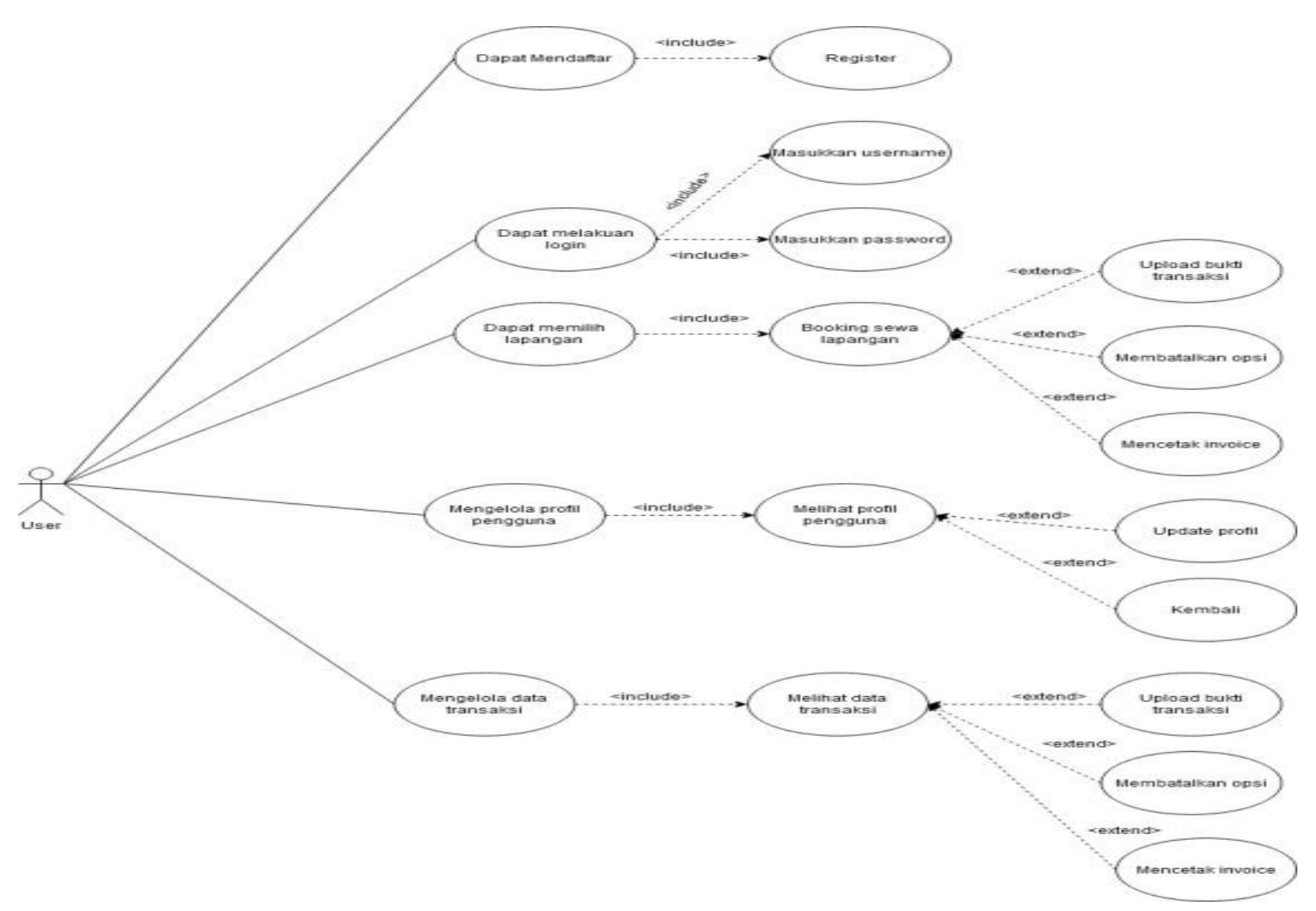

Gambar 2. Use Case Diagram user 


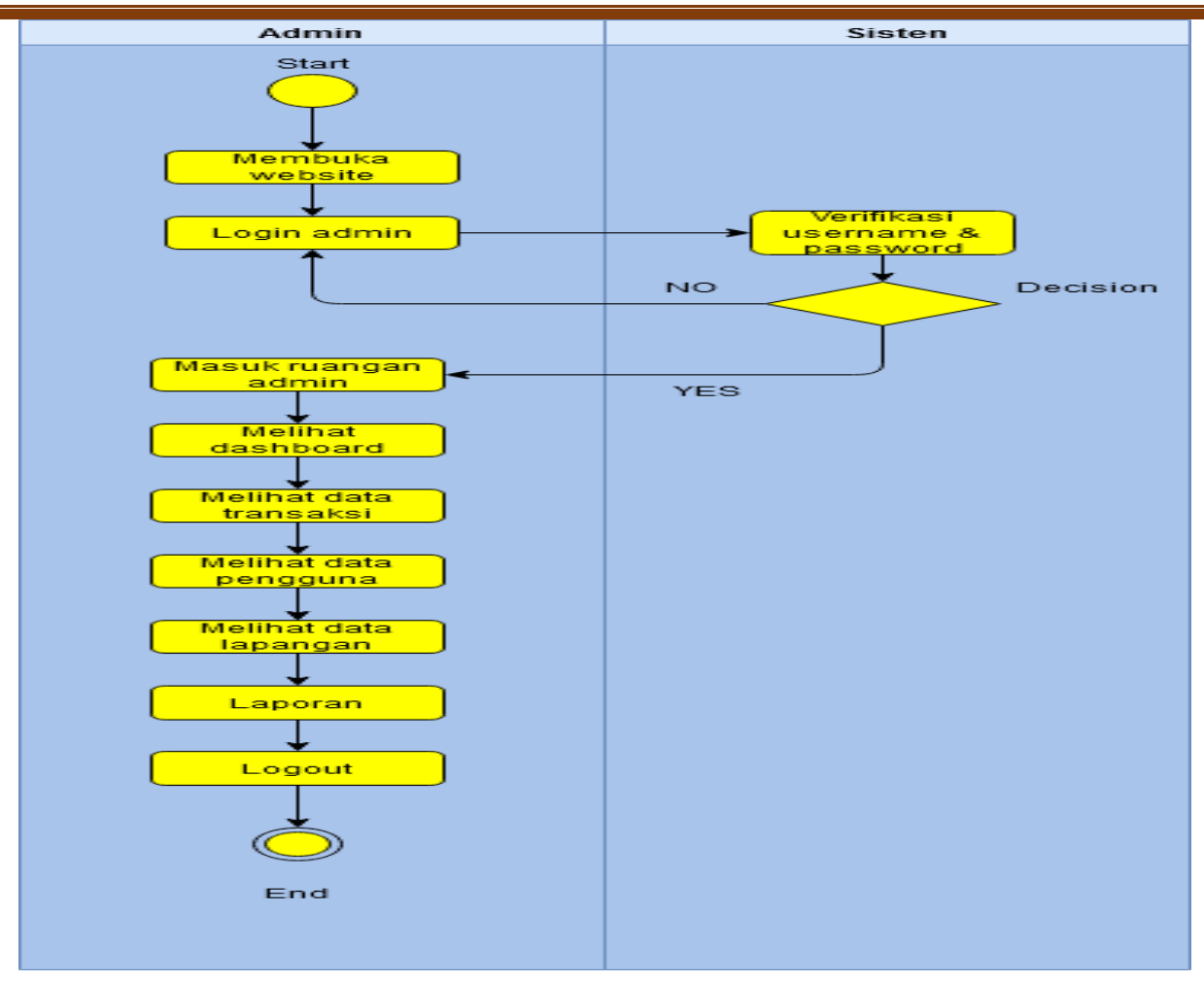

Gambar 3. Activity Diagram Admin

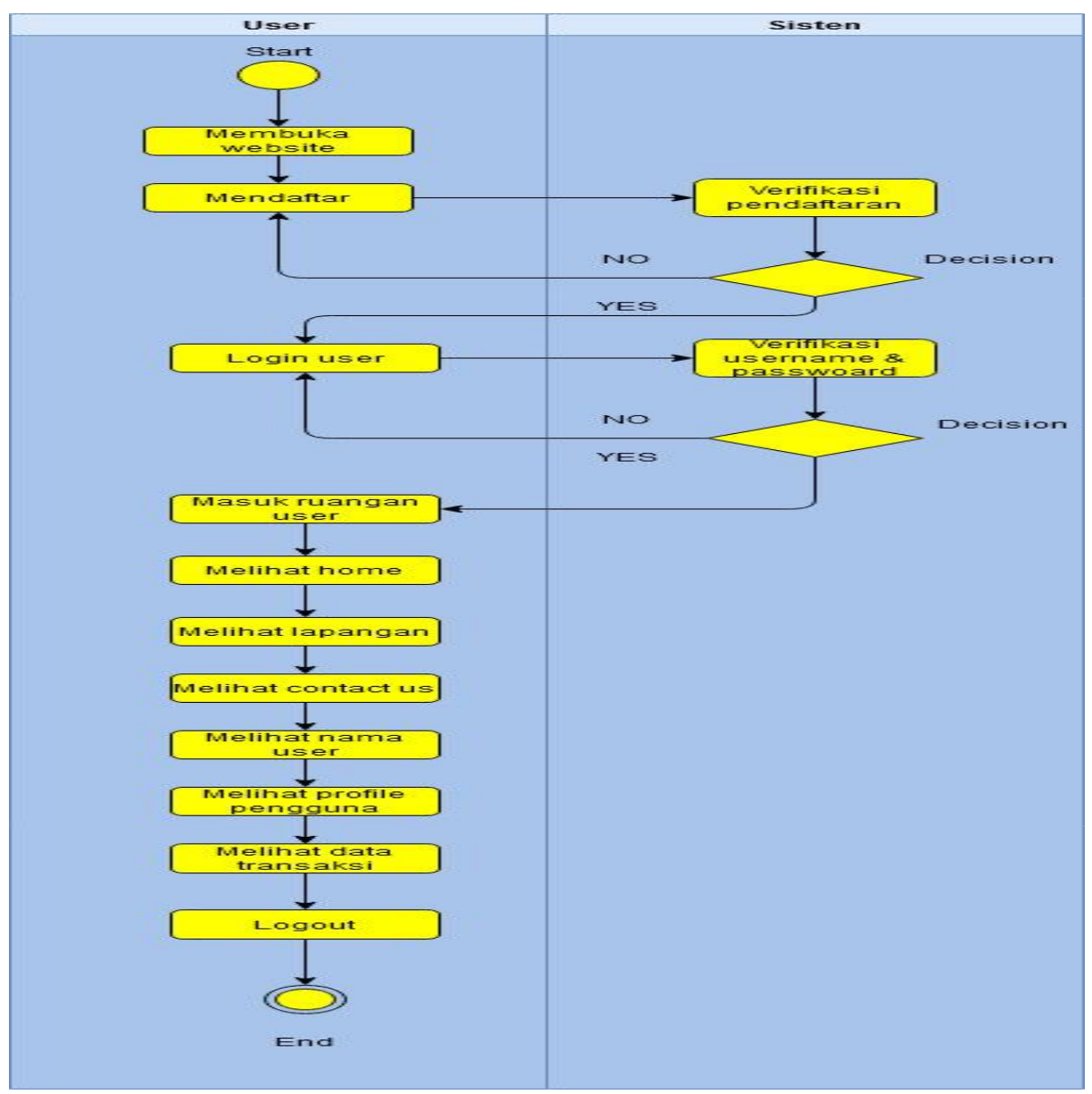

Gambar 4. Activity Diagram User 


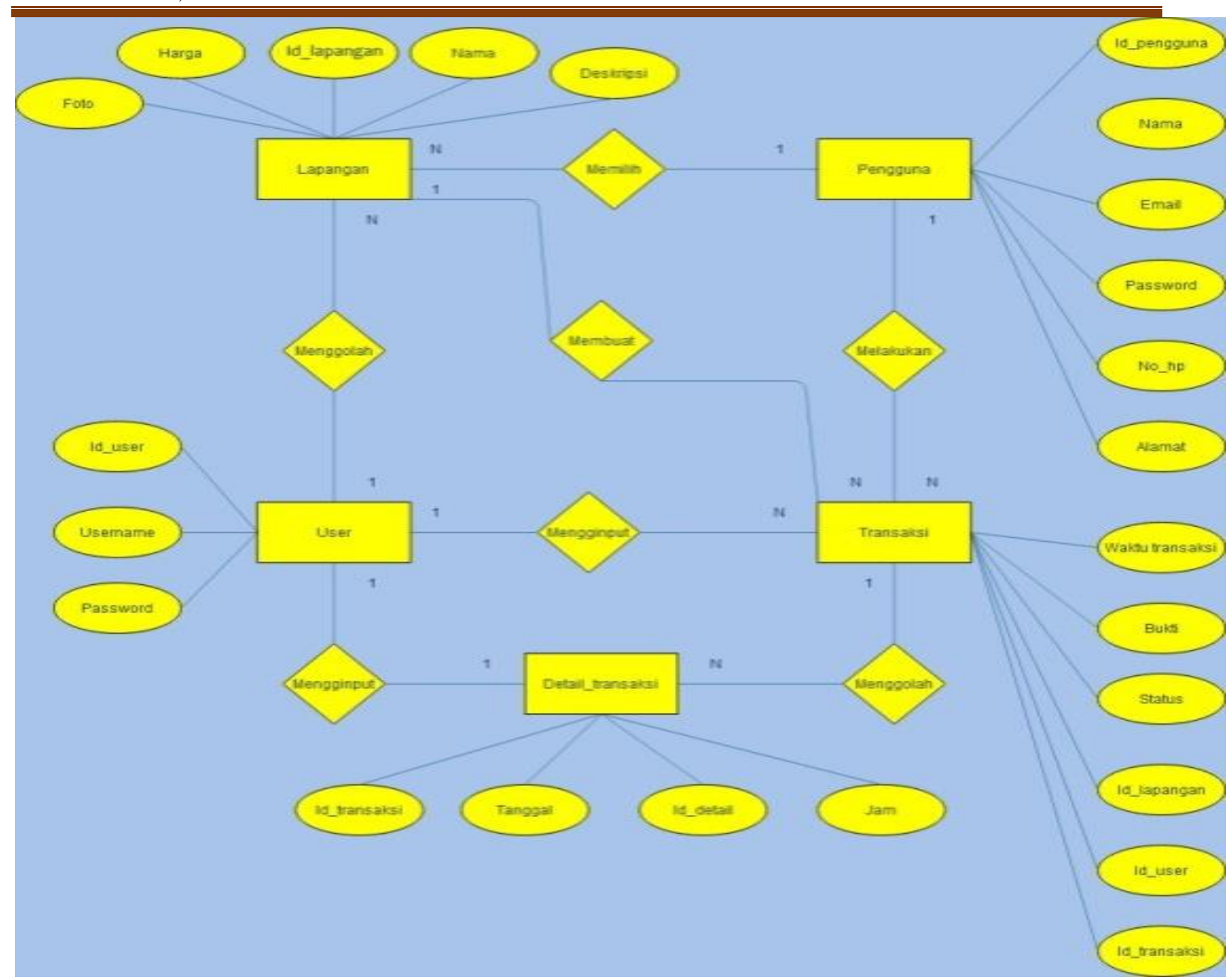

Gambar 5. Entity Relationship Diagram

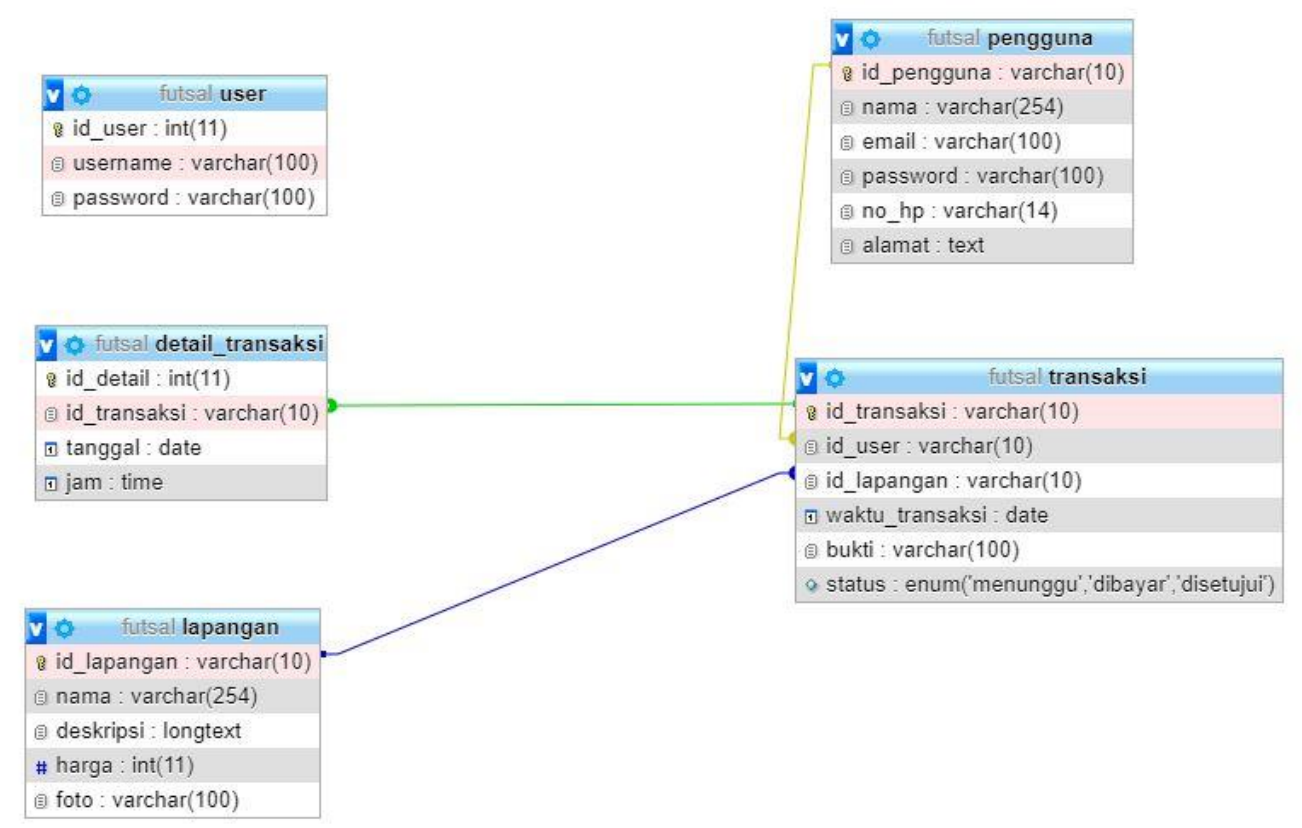

Gambar 6. Relasi Antar Tabel 
Rancangan User Interface 3R Futsal
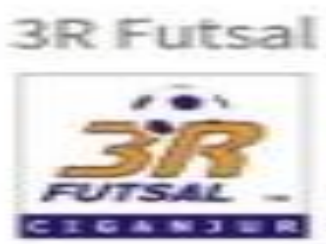

Sigen in to stemt your sessiforn

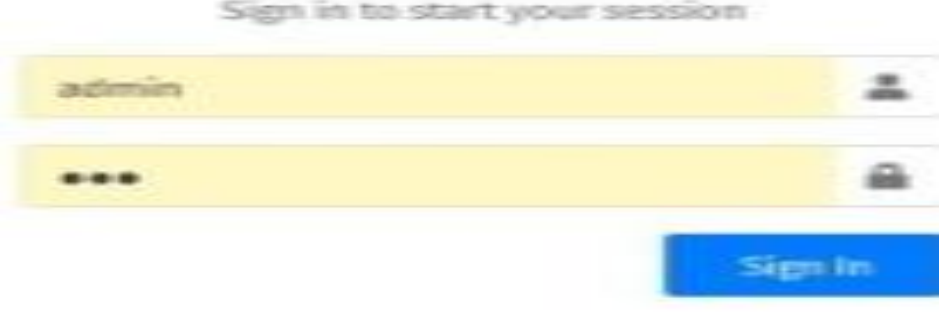

Gambar 7. Halaman Login Admin

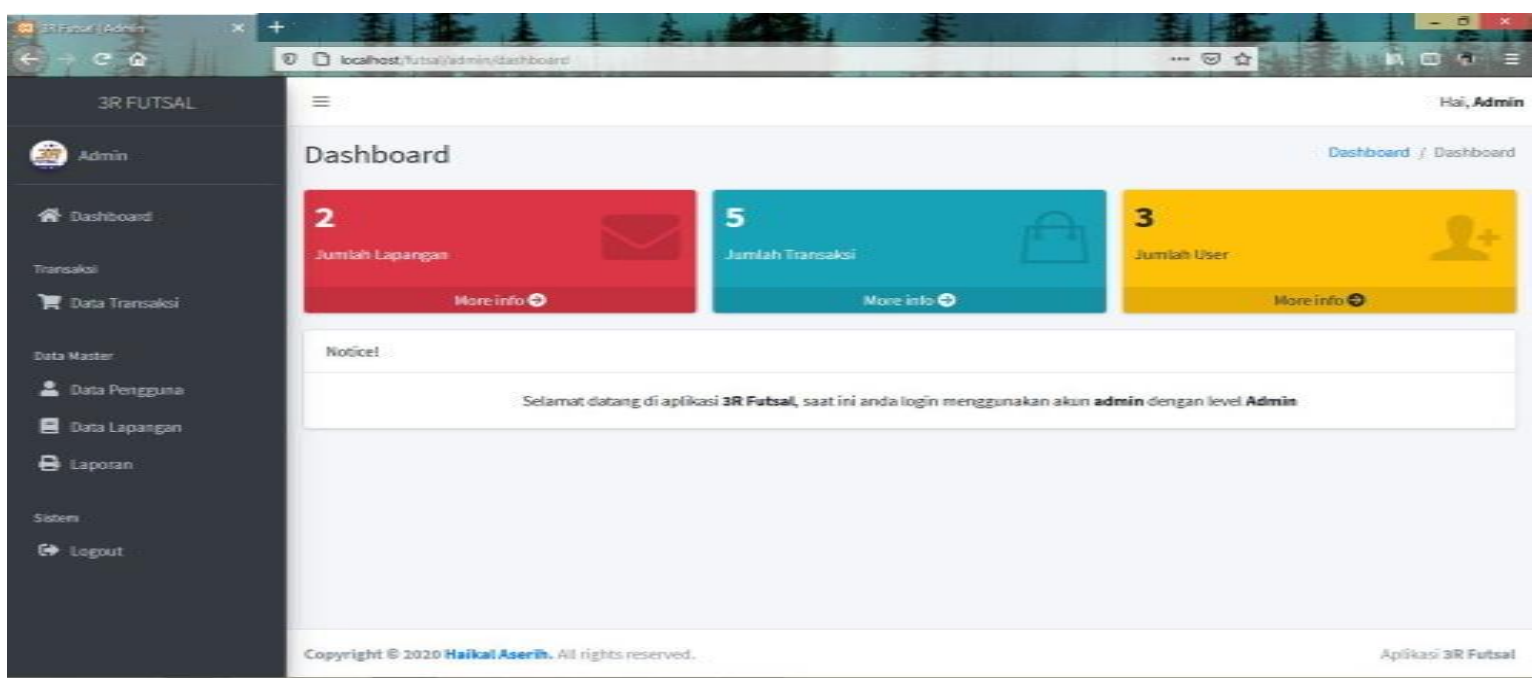

Gambar 8. Front-Page Admin
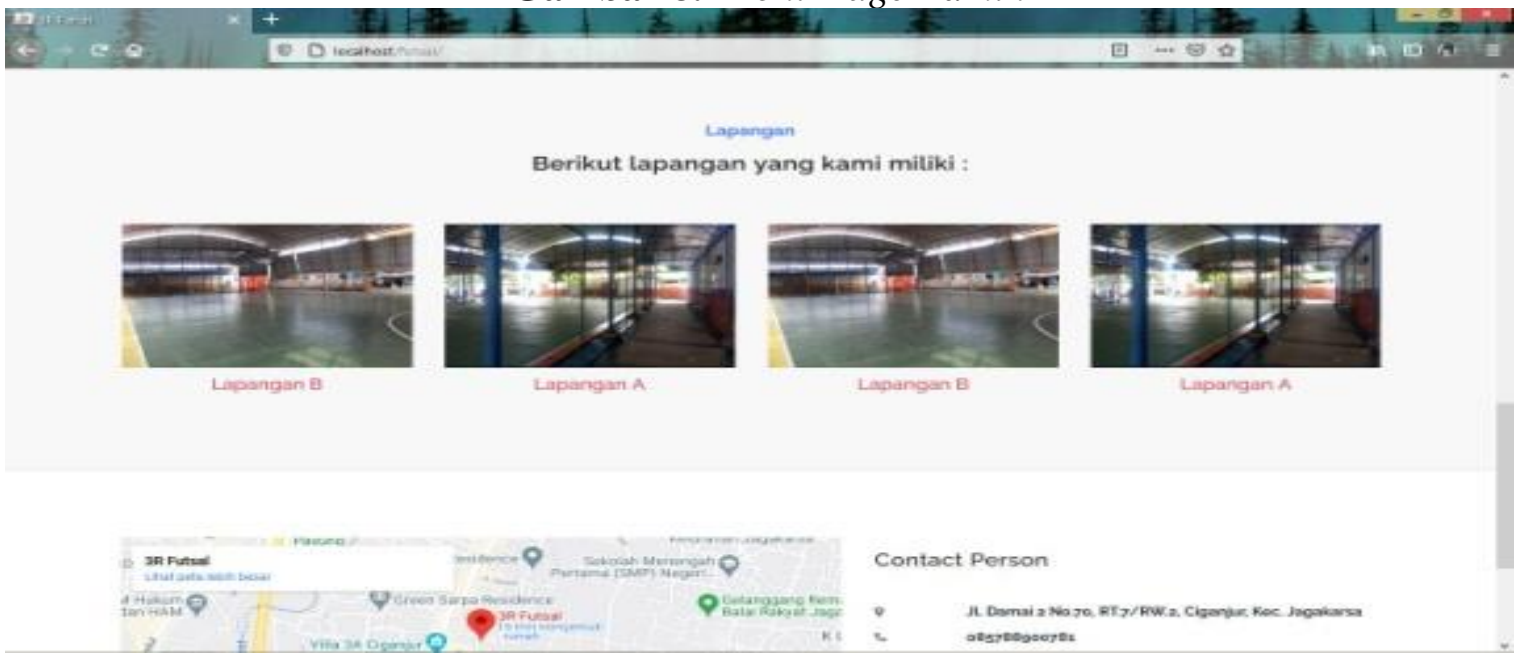

Gambar 10. Home User 
Tabel 1. Hasil Pengujian Black Box Testing Form Login Admin

\begin{tabular}{|c|c|c|c|c|c|}
\hline No & Skenario Penguji & Test Case & $\begin{array}{l}\text { Hasil Yang } \\
\text { Diharapkan }\end{array}$ & $\begin{array}{c}\text { Hasil } \\
\text { Penguji }\end{array}$ & Kesimpulan \\
\hline 1 & $\begin{array}{l}\text { Mengisi data login } \\
\text { manager untuk } \\
\text { username, lalu klik } \\
\text { 'Login' }\end{array}$ & $\begin{array}{l}\text { Username: } \\
\text { (kosong) } \\
\text { Password: } \\
\text { (kosong) }\end{array}$ & $\begin{array}{l}\text { Sistem akan } \\
\text { menolak akses } \\
\text { login dan akan } \\
\text { kembali ke } \\
\text { halaman awal } \\
\text { muncul dialog } \\
\text { "please fill out } \\
\text { this failed" }\end{array}$ & $\begin{array}{c}\text { Sesuai } \\
\text { harapan }\end{array}$ & Valid \\
\hline 2 & $\begin{array}{l}\text { Mengisi data login } \\
\text { manager untuk } \\
\text { username, lalu klik } \\
\text { 'Login' }\end{array}$ & $\begin{array}{l}\text { Username: } \\
\text { (admin) } \\
\text { Password: } \\
\text { (kosong) }\end{array}$ & $\begin{array}{c}\text { Sistem akan } \\
\text { menolak akses } \\
\text { login dan akan } \\
\text { kembali ke } \\
\text { halaman awal } \\
\text { muncul dialog } \\
\text { "please fill out } \\
\text { this failed" }\end{array}$ & $\begin{array}{c}\text { Sesuai } \\
\text { harapan }\end{array}$ & Valid \\
\hline 3 & $\begin{array}{l}\text { Mengisi data login } \\
\text { manager untuk } \\
\text { username, lalu klik } \\
\text { 'Login' }\end{array}$ & $\begin{array}{l}\text { Username: } \\
\text { (kosong) } \\
\text { Password: } \\
\text { (123) }\end{array}$ & $\begin{array}{l}\text { Sistem akan } \\
\text { menolak akses } \\
\text { login dan akan } \\
\text { kembali ke } \\
\text { halaman awal } \\
\text { muncul dialog } \\
\text { "please fill out } \\
\text { this failed" }\end{array}$ & $\begin{array}{c}\text { Sesuai } \\
\text { harapan }\end{array}$ & Valid \\
\hline 4 & $\begin{array}{l}\text { Mengisi data login } \\
\text { manager untuk } \\
\text { username, lalu klik } \\
\text { 'Login' }\end{array}$ & $\begin{array}{l}\text { Username: } \\
\text { (admin) } \\
\text { Password: } \\
\text { (salah) }\end{array}$ & $\begin{array}{c}\text { Sistem akan } \\
\text { menolak akses } \\
\text { login dan akan } \\
\text { kembali ke } \\
\text { halaman awal } \\
\text { muncul dialog } \\
\text { "Username / } \\
\text { Password Salah }\end{array}$ & $\begin{array}{c}\text { Sesuai } \\
\text { harapan }\end{array}$ & Valid \\
\hline 5 & $\begin{array}{l}\text { Mengisi data login } \\
\text { manager untuk } \\
\text { username, lalu klik } \\
\text { 'Login' }\end{array}$ & $\begin{array}{l}\text { Username: } \\
\text { (salah) } \\
\text { Password: } \\
\quad(123)\end{array}$ & $\begin{array}{c}\text { Sistem akan } \\
\text { menolak akses } \\
\text { login dan akan } \\
\text { kembali ke } \\
\text { halaman awal } \\
\text { muncul dialog } \\
\text { "Username / } \\
\text { Password Salah }\end{array}$ & $\begin{array}{c}\text { Sesuai } \\
\text { harapan }\end{array}$ & Valid \\
\hline 6 & $\begin{array}{l}\text { Mengisi data login } \\
\text { manager untuk } \\
\text { username, lalu klik } \\
\text { 'Login' }\end{array}$ & $\begin{array}{l}\text { Username: } \\
\text { (admin) } \\
\text { Password: } \\
\text { (123) }\end{array}$ & $\begin{array}{c}\text { Sistem akan } \\
\text { menerima akses } \\
\text { login dan } \\
\text { menampilkan } \\
\text { halaman } \\
\text { Dashboard } \\
\text { admin }\end{array}$ & $\begin{array}{c}\text { Sesuai } \\
\text { harapan }\end{array}$ & Valid \\
\hline
\end{tabular}

\section{KESIMPULAN DAN REKOMENDASI}

Dari pembahasan mengenai sistem informasi penyewaan lapangan futsal berbasis web diatas, dapat ditarik kesimpulan dari keseluruhan pokok pembahasan sebagai berikut: 
Perancangan website ini dapat membantu menyelesaikan masalah-masalah yang ada pada Lapangan Futsal 3R dalam meningkatkan kualitas proses penyewaan lapangan futsal. Dengan dibuatnya sistem informasi penyewaan lapangan futsal ini dapat memudahkan karyawan dalam pembuatan laporan penyewaan lapangan futsal setiap bulan atau setiap tahun. Sistem informasi penyewaan lapangan futsal berbasis web yang telah dirancang ini dapat dikembangkan lagi kedepannya sehingga website ini bisa lebih sempurna seperti meminimalisir kesalahan manusia atau human error.

Rekomendasi yang perlu dipertimbangkan yaitu:

Perlu diadakannya Pelatihan bagi pengguna (karyawan) agar pengguna dapat menggunakan sistem penyewaan ini dengan baik dan benar. Sistem informasi penyewaan lapangan futsal berbasis web perlu di maintenance dengan baik dan benar agar dapat mencapai tujuan yang diharapkan oleh pengelola. Perlu adanya backup data demi mencegah terjadinya hal hal yang tidak diinginkan misalnya hilangnya data atau kerusakan data.

\section{REFERENSI}

R. H. Swastika and F. N. Khasanah, "Sistem Informasi Reservasi Lapangan Futsal Pada Futsal Corner Menggunakan Metode Waterfall,” J. Mhs. Bina Insa., vol. 1, no. 2, pp. 251-266, 2017.

R. Sukamto and M. Shalahuddin, Rekayasa Preangkat Lunak Terstruktur dan Berorientasi Objek. Bandung: Informatika Bandung, 2015.

R. Asmara, "Sistem Informasi Pengolahan Data Penanggulangan Bencana Pada Kantor Badan Penanggulangan Bencana Daerah (BPBD) Kabupaten Padang Pariaman,” J. JClick, vol. 3, no. 2, pp. 80-91, 2016.

S. Apif and W. Dwi, Prabowo, "E-Commerce Pada Toko My Digital," J. Penelit. Dosen FIKOM, vol. 4, no. 1, pp. 1-7, 2017.

H. Nurmi, "Membangun Website Sistem Informasi Dinas Pariwisata," J. Edik Inform., vol. 1, no. 2, pp. 1-6, 2015.

C. Tristianto, "Penggunaan Metode Waterfall Untuk Pengembangan Sistem Monitoring dan Evaluasi Pembangunan,” J. Teknol. Inf., vol. 12, no. 1, pp. 8-22, 2018, doi: 10.1093/nq/182.23.321-a.

D. Sukrianto, "Penerapan Teknologi Barcode pada Pengolahan Data Pembayaran Sumbangan Pembinaan Pendidikan (SPP),” Intra-Tech, vol. 1, no. 2, pp. 18-27, 2017. 
A. Sukmaindrayana and R. Sidik, "Aplikasi Grosir Pada Toko RSIDIK Bungursari Tasimalaya,” J. Manaj. Inform., vol. 4, no. 2, pp. 31-40, 2017, [Online]. Available: https://www.cambridge.org/core/product/identifier/CBO9781107415324A009/type/bo ok_part.

A. Rosidi, H. Sismoro, Kursini, T. Luthfi, Emha, H. Fatta, AL, and A. Hartanto, Dwi, "Data Manajemen Dan Teknologi Informasi," J. Ilm. Data Manaj. dan Teknol. Inf., vol. 16, no. 4, pp. 17-22, 2015.

Suendri, "Implementasi Diagram UML (Unified Modelling Language) Pada Perancangan Sistem Informasi Remunerasi Dosen Dengan Database Oracle (Studi Kasus: UIN Sumatera Utara Medan)," J. Ilmu Komput. dan Inform., vol. 3, no. 1, pp. 1-9, 2018, [Online]. Available:

http://jurnal.uinsu.ac.id/index.php/algoritma/article/download/3148/181.

Sularno, "Sistem Informasi Promosi Dan Pemetaan Mitra Tambal Ban Menggunakan Location Based Service Berbasis Android Pada Ud Usaha Abadi,” J. Sains dan Inform., vol. 5, no. 2, pp. 78-82, 2019, [Online]. Available: http://jurnal.uinsu.ac.id/index.php/algoritma/article/download/3148/1871.

M. Destiningrum and Q. J. Adrian, "Sistem Informasi Penjadwalan Dokter Berbassis Web Dengan Menggunakan Framework Codeigniter (Studi Kasus: Rumah Sakit Yukum Medical Centre)," J. Teknoinfo, vol. 11, no. 2, p. 30, 2017, doi: 10.33365/jti.v11i2.24. R. V Palit, Y. D. Y. Rindengan, and A. S. M. Lumenta, "Rancangan Sistem Informasi Keuangan Gereja Berbasis Web Di Jemaat Gmim Bukit Moria Malalayang," J. Tek. Elektro dan Komput., vol. 4, no. 7, pp. 1-7, 2015, doi: 10.35793/jtek.4.7.2015.10458. 